\title{
REVIEW
}

\section{Philip A. Cunningham, Joseph Sievers, Mary Boys, Hans Herman Henrix, and Jesper Svartik, Eds. \\ Christ Jesus and the Jewish People Today: New Explorations of Theological Interrelationships}

(Grand Rapids, MI: Eerdmans, 2011), xxxii + 302 pp.

Eugene Korn, Center for Jewish-Christian Understanding and Cooperation, Israel

Modernity is a messy affair, full of dramatic change, pluralistic tension, and spiritual contradiction, and Christianity has not been spared this fate. The aggiornamento of the Second Vatican Council brought modern anxieties and antinomies into Christian theology, perhaps no more conspicuously than in the Catholic Church's relations to Jews and Judaism. Nostra Aetate rejected traditional supersessionism, thus creating a clash between the Church's universal mission and the continuing validity of God's covenant with the Jewish people, whose religious mission is said to still be operative. How can Christians reformulate their theologies in light of a living Judaism? After centuries of denying that "The covenant is both theirs [i.e., Jews] and ours [i.e., Christians]" (to quote the second-century Epistle of Barnabas [4:6]), the plight of today's Christian theologian is to wrestle with this theological conundrum.

In order to examine this tension, four Catholic universities arranged a series of consultations for Christian (largely Catholic) scholars from eight countries beginning in October 2006. The recently published collection of their essays (along with brief responses from Jewish scholars) gathered in Christ Jesus and the Jewish People Today represents the first fruits of this project. As Cardinal Walter Kasper explains in the volume's introduction, the dominant issue is how contemporary Christians can reaffirm Jesus Christ as savior of all humanity even as they affirm Israel's covenantal life with God. The book's contributors are amongst the best thinkers in the field and include John Pawlikowski, Jesper Svartik, Mary Boys, Christian Rutishauser, Phillip Cunningham, Didier Pollefeyt, Barbara Meyer, Hans Herman Henrix, and Thomas J. Norris. Together they are building a "Pro Judaeis" tradition (quoting Kasper on p. xii) under the aegis of contemporary doctrine to counter the Adversus Judaeos tradition which so burdens the consciousness of historically and ethically attuned Christians.

Right behind this meta-question is the related challenge of probing the implications of acknowledging that Jesus lived and died as a faithful Jew amidst the Jewish people in the Jewish homeland. What does this mean for Church history, ecclesiology, and Christology? Despite Karl Barth's 1947 announcement that "Jesus Christ was of necessity a Jew" unlike his accidents of skin color and gender (quoted by Meyer on p. 148), this remained a largely unexamined theological point until this book. Henrix puts it sharply: "The Word became Jewish flesh, not some sort of generic human being" (p. 123). Only a Jew could proclaim God's unity, His covenant, messianic redemption, and our human duties to "love the Lord your God with all thy heart and with all thy might" and to carry out a mission to the world. Meyer claims "If any God is present in Jesus Christ, it is the God of the Jews" (p. 152). So the Christian challenge is not merely to recollect 
that Jesus was a Jew (anamnesis), but to hold this critical point in continuous memory (mneme). How far do the consequences of all this touch the essentials of Christian belief?

The book's essays are also excurses in history, biblical hermeneutics, and liturgy. Pawlikowski reviews recent scholarship on "the parting of the ways" and concludes that taking historical Christian behavior toward Jews seriously creates a moral imperative to change Church doctrine. Boys discusses the consequences of seeing Jews as deicides. Clearly, the horror of the Holocaust is never far from the surface of both these thinkers' reflections. Svartvik offers a nonsupersessionist reading of Hebrews, claiming that the traditional supersessionist reading is "anachronistic" (p. 84), while Daniel J. Harrington provides the historical context of Paul and Matthew, insisting that they reflect intra-Jewish rivalry, not anti-Jewish polemics. Cunningham carefully rereads Romans for us. But at its core the book always returns to ask the questions and limn the theological changes entailed by the Church's new fraternal recognition of Judaism and the Jewish people.

Is this tension a problem to be solved through rational explanation or a divine mystery to be celebrated? While some cite the conundrum as an inexplicable mystery, importantly the book offers two specific and creative theological attempts to resolve the antinomy.

The essay by Cunningham and Pollefeyt provides the most explicit argument by building on Cardinal Kasper's one-covenant theory that asserts the simultaneous validity of the Jewish covenant and Christ as "universal redeemer" (p.183). Surprisingly, it is the insistence on one covenant that implies the necessity of Christians and Jews cooperating with each other. Although bound by the same covenant, Jews and Christians fulfill it and live it differently. The boldest claim in this argument is that by being faithful to the Sinai covenant, Jews covenant with Christianity's triune God, even if they do not realize it. This is possible because the authors define the Logos generically, as "the invitation to covenantal relation with God together with the Spirit that empowers the human acceptance of that outreach" (p. 195).

The Jewish commentator on this essay, Adam Gregerman, sees Cunningham and Pollefeyt's casting of Judaism in Christian trinitarian terms as "scandalous" to Jews (p. 224), yet I find no fault with it. Understanding Judaism as the covenantal life charged to the descendants of Abraham and Moses that results from "God's constant outreach for relationship with his covenantal people and their acceptance of that outreach" seems to me, as a traditional Jew, to be an accurate description of Jewish sacred history and the grand drama of Judaism (p. 195). If Cunningham and Pollefeyt's grammar demands they use a trinitarian vocabulary to describe that covenantal process, I may have problems with their semantics but not their ontology of the relationship between God and the Jewish people. I am curious to hear more, however, about how this generalized definition of the Logos is consistent with traditionalist understandings of the trinity.

Rutishauser asserts that salvation for Jews and Christians is only possible because of the unique salvation history of Sinai and the Jewish national covenant. To resolve the tension of universalist claims about Christ, he sees the Jewish covenant as the mission to be a light and messenger to the Gentile nations (Is 49:6 and Jer 1:10), and thus the Christian mission to Gentiles described in Galatians 2:7 is merely an outgrowth of the Jewish universal mission. (I add here that a number of traditional rabbinic exegetes understood Isaiah's and Jeremiah's descriptions of the Jewish covenantal mission as a correct interpretation of the Sinaitic commandment in Exodus 19:6 for Israel to be "a nation of priests.") For Rutishauser, Jesus "passed over," out of the realm of the Jewish people into the hands of the Gentiles (p. 236). He was torn out of the core of Israel's covenant and was handed over ("paradidonai") to the Romans, indicating that 
Jesus' mission consisted of crossing over the difference between the covenanted people (i.e., the Jews) and the nations. "Paradidonai" expresses only this extension to the Gentiles, and it is tendentious to understand it as "betrayal," as many traditionalists have done.

This reading leaves the original, particularist Sinai covenant and the Torah of Moses untouched for Jews, while charging Christians to extend the covenant outward to the Gentiles. As a consequence, there is no mission to the Jews, forcing evangelical scriptural passages like Matthew 28:16-20 to refer to all peoples except the Jews who already are people of God. After the resurrection, it is the apostles who teach us that the Christian mission is to "hand over the messiah to the (Gentile) world" (p. 241).

If Rutishauser is correct, Jews should be free to reconsider Christianity without any threat to their physical and spiritual identity. Indeed, there is every reason for Jews to consider Christians as their partners in fulfilling God's covenant. One may ask here, "What if any significance, then, does Jesus have for Jews? Is there any claim of Jesus on Jews before the eschaton?"

The book explores a number of other questions that flow from the meta-question, like the meaning of Jesus' eternity for Jewish identity, the implications of loving Jesus for Christian-Jewish relations, the relation of the trinity to Jewish monotheism, and the theological significance of Jesus' Jewishness.

Toward the end of the book the Jewish scholar Ruth Langer correctly observes that theological investigations are not enough. Endorsement of these new ideas by Church authorities and their concrete implementation into doctrine, liturgy, preaching, and dialogue must supplement these theological exercises. This is particularly important since, as Gregerman notes, the center of gravity of the Catholic Church is moving away from Europe toward countries with little knowledge of Jews, their religion, and the tortured Christian-Jewish history. Unfortunately, Cardinal Kasper was alone among the book's writers as one with a high-ranking position in the Church. Hopefully, the quality of the book's essays will attract the attention of ecclesiastical authorities to effect these needed developments.

In sum, this is a remarkable book written by a remarkable group of believers. Its most significant contribution is its reflection on the pregnant implications of the officially supported new theological coexistence between Christianity and Judaism in Christian thought. Excepting Cunningham / Pollefeyt and Rutishauser, the writers do not attempt to provide comprehensive answers. But their articulation of central questions and challenges for Christian theology are significant cognitive and spiritual gestures. The authors have staked out but the beginning of unfinished business, which needs to be pursued in subsequent iterations of the project. In the best of worlds, the book would create a new field in Christian theology devoted to the issues its authors raise, or at least broaden the contours of contemporary ecclesiology, Christology, and soteriology.

This hope is a worthy prayer, for Christians and Jews alike. 